Jurnal Edumath, Volume 6(1) th 2020 Hlm. 1-7

ISSN Cetak : 2356-2064

ISSN Online : 2356-2056

\title{
PENINGKATAN KEMAMPUAN KONEKSI MATEMATIS MAHASISWA BERBASIS RECIPROCAL TEACHING PADA MATA KULIAH STATISTIKA DASAR
}

\author{
Tika Dwi Nopriyanti ${ }^{1)}$, Allen Marga Retta ${ }^{2)}$ \\ ${ }^{1,2}$ FKIP Pendidikan Matematika, Universitas PGRI Palembang \\ ${ }^{1}$ Email: tikadwinop@gmail.com \\ ${ }^{2}$ Email: allenmargaretta1@gmail.com
}

\begin{abstract}
Mathematical connection ability (MCA) is very important in applying mathematics in everyday life and with other sciences. Therefore, researchers want to improve the MCA of students with reciprocal teaching (RT) based learning strategies.. This study uses a quasi-experimental method with a non-equivalent pretest and posttest control group design of this study. 43 second semester mathematics education students consisting of 2 classes, namely the experimental class and the control class. At the end of the study, n-gain was obtained for classes with RT-based learning strategies of 0.43 while conventional classes obtained n-gain of 0.32, this shows that RT-based learning strategies can improve student MCA.
\end{abstract}

Keywords: connection ability, reciprocal teachin.

\begin{abstract}
Abstrak
Kemampuan koneksi matematis (KKM) adalah hal yang sangat penting dalam mengaplikasikan matematika dikehidupan sehari-hari maupun dengan ilmu lain. Oleh karena itu peneliti ingin meningkatkan KKM mahasiswa dengan strategi pembelajaran berbasis reciprocal teaching (RT). Penelitian ini menggunakan metode kuasi-eksperimen dengan desain kelompok kontrol pretes dan postes nonekuivalen subyek penelitian ini 43 mahasiswa Pendidikan Matematika semester II yang terdiri dari 2 kelas yaitu kelas eksperimen dan kelas kontrol. Diakhir penelitian diperoleh n-gain untuk kelas yang strategi pembelajaran berbasis RT sebesar 0,43 sedangkan kelas konvesional diperoleh n-gain sebesar 0,32 hal ini menunjukkan bahwa dengan strategi pembelajaran berbasis $R T$ dapat meningkatkan KKM mahasiswa.
\end{abstract}

Kata Kunci: kemampuan koneksi, reciprocal teaching

1. PENDAhUluan

National Council of Teacher of

Mathematics (NCTM) (2000) menentukan

lima kemampuan standar yang harus dimiliki siswa dalam belajar matematika yaitu kemampuan pemecahan masalah, kemampuan penalaran, kemampuan komunikasi, kemampuan membuat koneksi (connection), dan kemampuan representasi. Salah satu dari lima kemampuan tersebut 
Peningkatan Kemampuan Koneksi Matematis Mahasiswa Berbasis Reciprocal Teaching Pada Mata Kuliah Statistika Dasar

adalah kemampuan koneksi matematis (KKM).

Koneksi matematis adalah pengaitan matematika dengan pelajaran lain atau topik lain. Menurut NCTM (1989), ada dua tipe umum koneksi matematik, yaitu modeling connections dan mathematical conections. Modeling connections merupakan hubungan antara situasi masalah yang muncul di dunia nyata atau dalam disiplin ilmu lain dengan representasi matematiknya, sedangkan mathematical connections adalah hubungan antara dua representasi yang ekuivalen, dan antara proses penyelesaiannya. Dari pengertian tersebut, koneksi matematika dapat diindikasikan dalam tiga aspek yaitu: koneksi antar topik matematika, koneksi dengan disiplin ilmu lain, dan koneksi dengan dunia nyata siswa/ koneksi dengan kehidupan sehari-hari.

Akan tetapi kenyataannya KKM masih kurang berkembang. Hal ini terlihat ketika mahasiswa sebagai calon pendidik menentukan solusi dalam menyelesaikan soal matematika khususnya pada matakuliah statistika yang begitu banyak digunakan dalam kehidupan sehari-hari kurang tepat. Hal ini salah satunya disebabkan karena mahasiswa tidak menyukai statistika karena identik dengan rumus atau teori. Leibman (2010: 15) menjelaskan bahwa mahasiswa kurang tertarik terhadap Statistika salah satunya dikarenakan pembelajaran Statistika masih menggunakan format kuliah tradisional dan model transfer pengetahuannya masih tetap menjadi metode andalan. Selain itu juga Shi (2009) menyatakan statistika masih diajarkan secara teoritis dan kurang terhubung ke dunia nyata. Sejalan dengan itu Faqih (2012) mengindikasikan bahwa mahasiswa selama ini mempelajari statistika maupun matematika secara prosedural. Statistika hanya sebagai alat untuk menghitung sesuatu tanpa makna dan konsep yang jelas. Hal ini dikhawatirkan akan membuat mahasiswa melihat matematika dan statistika adalah ilmu yang abstrak dan tidak bisa diaplikasikan dalam kehidupan seharihari. Hal ini juga menunjukkan bahwa kemampuan koneksi matematis mahasiswa masih sangat kurang.

Menghindari kebosanan mahasiswa dalam belajar statistika sebagai tenaga pendidik sebaiknya strategi pembelajaran yang digunakan haruslah inovatif dan tidak membosankan bagi peserta didik sehingga proses belajar mengajar lebih efektif dan efisien sehingga tujuan pembelajaran tercapai. Strategi pembelajaran yang digunakan seorang dosen sangatlah penting untuk menciptakan suasana belajar mengajar yang produktif salah satu strategi 
Tika Dwi Nopriyanti, Allen Marga Retta

pembelajaran yang dapat digunakan adalah strategi pembelajaran berbasis Reciprocal Teaching (RT).

Strategi pembelajaran berbasis Reciprocal Teaching (RT) dalam proses belajarnya siswa dilatih untuk memahami suatu masalah dan memberikan penjelasan pada teman sebaya, sehingga para ahli banyak yang menyebut reciprocal teaching ini sebagai peer practice (latihan dengan teman sebaya). Qohar (2010) menyatakan bahwa salah satu upaya yang dapat menunjang proses pembelajaran untuk meningkatkan kemampuan koneksi, pemahaman matematis, dan komunikasi matematis serta kemandirian belajar matematika siswa, untuk siswa yang pembelajarannya menggunakan reciprocal teaching lebih baik daripada siswa yang pembelajarannya dilakukan secara konvensional.

Palinscar (1986) reciprocal teaching bisa disusun dengan menggunakan empat strategi yang bisa diterapkan secara fleksibel yaitu:

\section{Menyimpulkan (summarization)}

Pada strategi summarization mahasiswa memahami dan menyimpulkan suatu naskah dan memberikan penjelasan pada teman sebaya. Naskah yang diberikan pada penelitian ini adalah lembar kerja mahasiswa (LKM) yang telah dibuat peneliti dan mahasiswa mengerjakannya secara berkelompok. Pada tahap ini kemampuan koneksi yang berkembang yaitu mengeksplorasi masalah dan menjelaskan hasilnya dengan grafik numeric, fisik, aljabar, dan model matematika

\section{Membuat pertanyaan (question generation)}

Mahasiswa membuat pertanyaan-pertanyaan dari LKM yang sudah dibacanya. Dengan membuat pertanyaan-pertanyaan mahasiswa bisa lebih memahami metakognisinya, mahasiswa menjadi lebih tahu tentang hal-hal yang dimengertinya dan hal-hal yang tidak dimengertinya. Kemampuan koneksi mahasiswa akan muncul yaitu mengeksplorasi masalah dan menjelaskan hasilnya dengan grafik numeric, fisik, aljabar, dan model matematika dan menghubungkan prosedur dengan representasi yang ekuivalen.

\section{Klarifikasi (clarification)}

Mahasiswa menjawab pertanyaan-pertanyaan yang sudah diajukan oleh teman dalam kelompoknya. Dengan menjawab pertanyaan yang diajukan, mahasiswa akan menjadi lebih paham tentang apa yang sudah diketahuinya dan terjadi pertukaran pendapat antar kelompok, sehingga mahasiswa yang mempunyai pemahaman yang kurang benar akan bisa diluruskan. Sehingga seiap kelompok sudah siap 
untuk memaparkan hasil diskusi kelompok mereka di depan kelas kepada teman-teman kelompok lain. Dengan menjawab pertanyaan yang diajukan, kemampuan koneksi matematis yang muncul yaitu menggunakan koneksi antara matematika dengan disiplin ilmu lain, menggunakan koneksi antar topic matematika, menghubungkan prosedur antar representasi ekuivalen, menerapkan pemikiran dan pemodelan matematika untuk menyelesaikan masalah yang muncul pada disiplin ilmu lain, dan mengeksplorasi masalah dan menjelaskan hasilnya dengan grafik numeric, fisik, aljabar, dan model matematika.

\section{Memprediksi (prediction).}

Setelah selesai menjawab dan menjelaskan pertanyaan-pertanyaan dalam kelompok, mahasiswa dituntut untuk memprediksi pertanyaan-pertanyaan lanjutan. Pada tahap terakhir ini kemampuan koneksi yang muncul menggunakan koneksi antar topic matematika, menghubungkan prosedur antar representasi ekuivalen, menerapkan pemikiran dan pemodelan matematika untuk menyelesaikan masalah yang muncul pada disiplin ilmu lain, representasi simbolik,enaktif dan ikonik.

Berdasarkan alasan di atas dilakukan upaya untuk meningkatkan kemampuan koneksi matematis mahasiwa.

\section{METODE PENELITIAN}

Penelitian ini merupakan penelitian Quasi-Experimental karena subjek tidak dikelompokkan secara acak, tetapi diterima apa adanya (Ruseffendi,2005). Pemilihan tipe Quasi-Experimental ini dengan pertimbangan bahwa kelas yang ada telah terbentuk sebelumnya dan mahasiswa telah mendaftar sesuai dengan kurikulum yang ada, sehingga tidak dilakukan lagi pengelompokan secara acak.

Penelitian ini dilakukan di Program Studi Pendidikan Matematika kepada 43 mahasiswa yang mengikuti matakuliah statistika dasar pada semester genap tahun ajaran 2018-2019 yang terdiri dari 2 kelas. 22 mahasiswa kelas A dan 21 mahasiswa kelas B. Penelitian ini bertujuan untuk meningkatkan kemampuan koneksi matematis (KKM) mahasiswa menggunakan strategi pembelajaran Reciprocal Teaching (RT).

Variabel dalam penelitian ini terdiri dari variabel bebas yaitu strategi pembelajaran $R T$, variabel terikatnya adalah KKM dan variabel kontrolnya yaitu Kemampuan Awal Mahasiswa (KAM).

Instrumen penelitian ini adalah tes. Tes dilakukan diawal (pretest) dan diakhir pertemuan (postes) untuk melihat peningkatan KKM. Sebelum digunakan 
Tika Dwi Nopriyanti, Allen Marga Retta

pengembangan soal tes divalidasi terlebih dahulu oleh dua orang dosen matematika. Teknik analisis data dilakukan setelah postest dilakukan untuk menghintung $n$-gain dengan menganalisis jawaban mahasiswa berdasarkan indikator KKM mahasiwa dengan membandingkan dengan skor prestes masing-masing mahasiswa secara keseluruha maupun sesuai KAM (tinggi, sedang, rendah)

Untuk mengetahui besarnya

peningkatan KKM pada kelas eksperimen (RT) dan kelas kontrol (KK). Langkahlangkah analisis data adalah sebagai berikut:

a. Menghitung besar peningkatan dengan rumus gain ternomalisasi (normalized gain), yaitu:

$n$-gain $=$

$\frac{\text { posttest score-pretest score }}{\text { imum possible score-pretest score }}$

(Hake, 1999)

b. Menginterpretasikan hasil perhitungan $n$ gain dengan menggunakan klasifikasi dari Hake (1999) yang dapat dilihat pada Tabel 1 berikut.

Tabel 1 Kategori $N$-Gain $(g)$

\begin{tabular}{cc}
$N$-Gain $(g)$ & Interpretasi \\
$g>0,7$ & Tinggi \\
$0,3<g \leq 0,7$ & Sedang \\
$g \leq 0,3$ & Rendah \\
\hline
\end{tabular}

\section{HASIL DAN PEMBAHASAN}

Pada awal pertemuan peneliti melakukan pretest untuk mengukur KAM dan diperoleh hasilnya pada Tabel 2 sebagai berikut:

Tabel 2

Statistik Deskriptif Data TKAM berdasarkan Kelas Sampel Penelitian

\begin{tabular}{cccccc}
\hline \multirow{2}{*}{ Kelas } & \multicolumn{2}{c}{ Skor } & Rerata & $\begin{array}{c}\text { Simpangan } \\
\text { Baku }\end{array}$ & \multirow{N}{*}{} \\
RT & 0 & 20 & 54,09 & 18,36 & 22 \\
KK & 0 & 20 & 54,5 & 17,74 & 21 \\
\hline
\end{tabular}

Berdasarkan Tabel 2 statistik deskriptif data KAM diatas diperoleh rerata untuk kelas yang menggunakan strategi pembelajaran RT sebesar 54,09 dan rerata kelas konvensional (KK) sebesar 54,5 dan ini menunjukkan bahwa rerata kemampuan kedua kelas tersebut relatif sama. Data pada Tabel 3 berikut adalah hasil distribusi mahasiswa berdasarkan data KAM.

Tabel 3.

Distribusi Mahasiswa berdasarkan KAM dan Pembelajaran

\begin{tabular}{cccc}
\hline \multirow{2}{*}{ KAM } & \multicolumn{2}{c}{ Pembelajaran } & Jumlah \\
Tinggi & RT & K & 7 \\
Sedang & 3 & 4 & 7 \\
Rendah & 4 & 14 & 29 \\
Jumlah & 22 & 3 & 7 \\
\hline
\end{tabular}

Setelah itu pembelajaran berlangsung 6 kali pertemuan dan di kelas yang menggunakan strategi RT diberikan LKM yang dikerjakan tiap kelompok. Di pertemuan terakhir dilakukan postes untuk melihat hasil akhir pembelajaran. Beradasarkan analisis peneliti dari skor pretes, postes dan n-gain diperoleh hasil pada Tabel 4 sebagai berikut: 
Tabel 4

Data Deskriptif Kemampuan Koneksi Matematis Mahasiswa berdasarkan KAM

\begin{tabular}{|c|c|c|c|c|c|c|c|c|c|c|}
\hline \multirow{2}{*}{$\begin{array}{l}\text { Kelompok } \\
\text { KAM }\end{array}$} & \multicolumn{5}{|c|}{ PRT } & \multicolumn{5}{|c|}{ PK } \\
\hline & $N$ & Stat. & \begin{tabular}{|l} 
Pretes \\
\end{tabular} & Postes & $\langle g\rangle$ & $n$ & Stat. & Pretes & \begin{tabular}{|l|} 
Postes \\
\end{tabular} & $\langle g\rangle$ \\
\hline \multirow{2}{*}{ Keseluruhan } & \multirow{2}{*}{22} & $\bar{x}$ & 11 & 15,09 & 0,43 & \multirow{2}{*}{21} & $\bar{x}$ & 10,9 & 13,9 & 0,32 \\
\hline & & $s$ & 3,68 & 2,49 & 0,26 & & $s$ & 3,55 & 2,72 & 0,21 \\
\hline \multirow{2}{*}{ Tinggi } & \multirow{2}{*}{3} & $\bar{x}$ & 16,3 & 18 & 0,4 & \multirow{2}{*}{4} & $\bar{x}$ & 15,5 & 17,25 & 0,375 \\
\hline & & $s$ & 1,15 & 1,73 & 0,24 & & $s$ & 0,58 & 0,96 & 0,3 \\
\hline \multirow{2}{*}{ Sedang } & \multirow{2}{*}{15} & $\bar{x}$ & 11,6 & 14,8 & 0,45 & \multirow{2}{*}{13} & $\bar{x}$ & 10,5 & 14 & 0,38 \\
\hline & & $s$ & 3,84 & 3,98 & 0,33 & & $s$ & 0,315 & 2,73 & 0,19 \\
\hline \multirow{2}{*}{ Rendah } & \multirow[b]{2}{*}{4} & $\bar{x}$ & 5 & 10 & 0,48 & \multirow[b]{2}{*}{4} & $\bar{x}$ & 8,8 & 12,4 & 0,31 \\
\hline & & $s$ & 1,63 & 4,54 & 0,11 & & $s$ & 3,63 & 2,51 & 0,17 \\
\hline
\end{tabular}

Berdasarkan Tabel 4 data deskriptif

KKM dapat dilihat bahwa baik secara keseluruhan maupun berdasarkan KAM skor $n$-gain kelas yang menggunakan strategi pembelajaran RT lebih besar dibandingkan dengan kelas menggunakan pembelajaran konvensional (PK). Hal ini menunjukkan bahwa strategi pembelajaran reciprocal teaching dapat meningkatkan kemampuan koneksi matematis mahasiswa secara keseluruhan maupun berdasarkan KAM (tinggi, sedang, rendah)

\section{KESIMPULAN}

Berdasarkan hasil analisis yang dilakukan dapat disimpulkan bahwa:

1. Secara keseluruhan kemampuan koneksi matematis mahasiswa yang pembelajarannya menggunakan strategi pembelajaran reciprocal teaching lebih besar peningkatannya dengan n-gain sebesar 0,43 dibandingkan dengan kelas yang menggunakan pembelajaran secara konvensional dengan $n$-gain sebesar 0,32.
2. Skor n-gain untuk perkemampuan awal (tinggi, sedang, rendah) kelas yang menggunakan strategi pembelajaran RT lebih besar daripada kelas konvensional.

\section{DAFTAR PUSTAKA}

Faqih, Abdul. (2012). Pengembangan Model Tutorial Statistik Dengan Metode (APOS) Aksi, Proses, Obyek dan Skema Di UPBJJ-UT Surabaya. Jurnal Gamatika Vol. III No.1 Nopember 2012. Surabaya: Universitas Terbuka UPBJJ.

Hake, R, R. (1999). Analyzing Change/Gain Score.AREA-D American Education Research Association's Devision. D, Measurement and Research Methodology.

Leibman, Zipora. (2010). Integrating RealLife Data Analysis in Teaching Descriptive Statistics: A Constructivist Approach. Journal of Statistic Education. 18, (1). [Online]. Tersedia pada:

www.amstat.org/publications/jse/v18n1 /libman.pdf. [7 Maret 2015].

NCTM. 2000. Principles and Standarts for School Mathematic.Reston, VA: NCTM. . 1989. Curriculum and Evaluation Standars for School Mathematics. Reston, VA: NCTM

Palinscar, A. \& Brown, A. (1984). Reciprocal Teaching in Comprehension-Fostering and Comprehension-Monitoring Activities Cognition and Instruction. [online] Tersedia di: http://teams.lacoe.edu/documentation/ classroom/patti/2-3/teacher/ 
Tika Dwi Nopriyanti, Allen Marga Retta

resources/reciprocal.html [3 April 2016]

Ruseffendi, E. T. (2005). Dasar-dasar Penelitian Pendidikan dan Bidang Non Eksakta Lainnya. Bandung: Tarsito

Shi,Ning-zhong. 2009. Understanding Statistic and Statistiscs Education:A Chinese Perspektive. Journal of Statistic education. 17 (3), (1-8). [Online]. Tersedia pada: www.amstat.org/publications/jse/v18 n1/libman.pdf. [7 Maret 2015]. 